\title{
Teaching NeuroImages: Gasperini syndrome
}

Raffaele lorio, MD, PhD

Neurology ${ }^{\circledR}$ 2018;90:e261. doi:10.1212/WNL.0000000000004836
Correspondence

Dr. Iorio

raffaele.iorio@

policlinicogemelli.it

Figure 1 Brain MRI
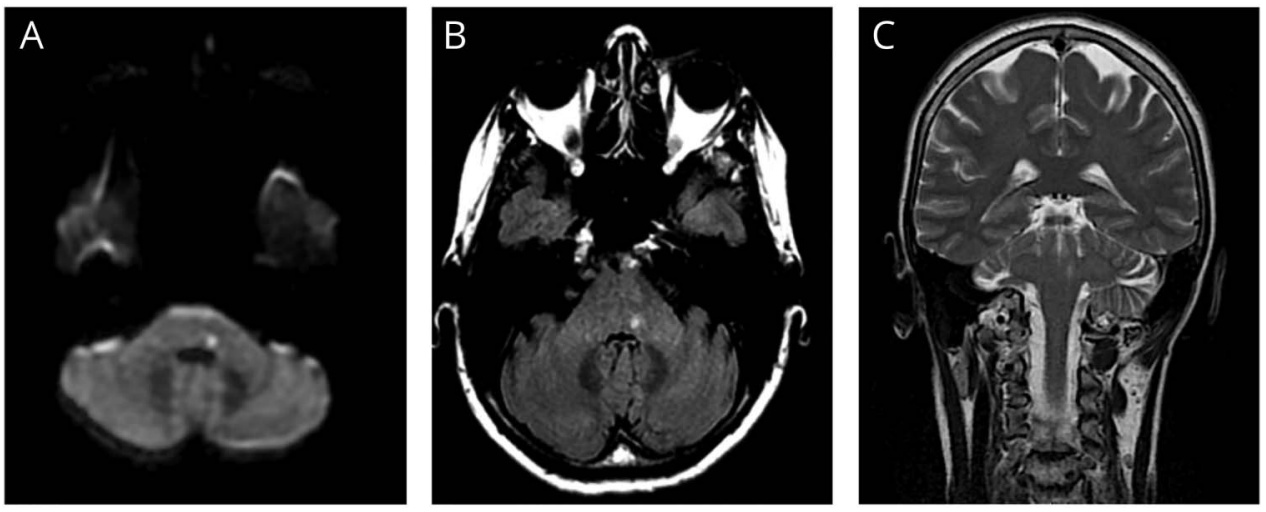

Brain MRI shows restricted diffusion in the caudal portion of the left pons (A) with corresponding hyperintensity on axial fluid-attenuated inversion recovery $(B)$ and coronal T2-weighted images (C).

A 62-year-old woman acutely developed left facial weakness, diplopia on left gaze, and rightsided numbness including her face. Brain MRI revealed an ischemic lesion of the lower pontine tegmentum (figure 1).

Gasperini syndrome is a rare crossed brainstem syndrome characterized by ipsilateral impairment of the VI, VII, and occasionally VIII cranial nerves and contralateral sensory loss. The syndrome, initially described by Ubaldo Gasperini in 1912, results from a lesion of the caudal pons tegmentum ${ }^{1,2}$ (figure e-1, links.lww.com/WNL/A47). The most frequent cause is the occlusion of the long circumferential branch of the anterior inferior cerebellar artery.

\section{Study funding}

No targeted funding reported.

\section{Disclosure}

R. Iorio reports no disclosures relevant to the manuscript. Got to Neurology.org for full disclosures.

\section{References}

1. Tacik P, Alfieri A, Kornhuber M, Dressler D. Gasperini's syndrome: its neuroanatomical basis now and then. J Hist Neurosc 2012;21: $17-30$.

2. Hayashi-Hayata M, Nakayasu H, Doi M, Fukada Y, Murakami T, Nakashima K. Gasperini syndrome, a report of two cases. Intern Med 2007;46:129-133.

\section{MORE ONLINE}

$\rightarrow$ Download teaching slides:

links.lww.com/WNL/A124 


\title{
Neurology
}

\author{
Teaching NeuroImages: Gasperini syndrome \\ Raffaele Iorio \\ Neurology 2018;90;e261 \\ DOI 10.1212/WNL.0000000000004836
}

This information is current as of January 15, 2018

Updated Information \&
Services

References

Subspecialty Collections

Permissions \& Licensing

Reprints including high resolution figures, can be found at: http://n.neurology.org/content/90/3/e261.full

This article cites 2 articles, 0 of which you can access for free at: http://n.neurology.org/content/90/3/e261.full\#ref-list-1

This article, along with others on similar topics, appears in the following collection(s):

All Cerebrovascular disease/Stroke

http://n.neurology.org/cgi/collection/all_cerebrovascular_disease_strok e

All Clinical Neurology

http://n.neurology.org/cgi/collection/all_clinical_neurology

Information about reproducing this article in parts (figures,tables) or in its entirety can be found online at:

http://www.neurology.org/about/about_the_journal\#permissions

Information about ordering reprints can be found online:

http://n.neurology.org/subscribers/advertise

Neurology ${ }^{\circledR}$ is the official journal of the American Academy of Neurology. Published continuously since 1951 , it is now a weekly with 48 issues per year. Copyright Copyright (C) 2018 American Academy of Neurology. All rights reserved. Print ISSN: 0028-3878. Online ISSN: 1526-632X.

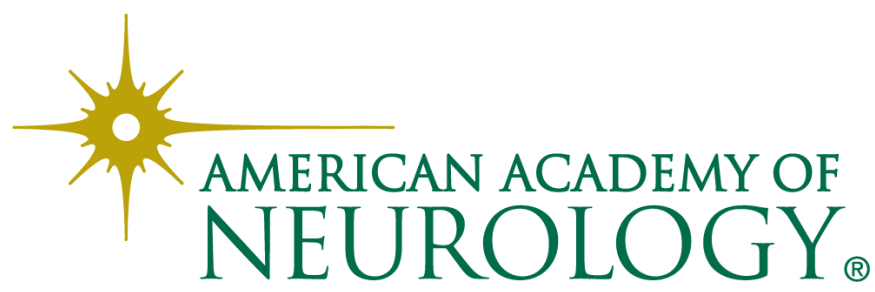

